\title{
Response of Elite Sugarcane Varieties / Genotypes to Higher Nitrogen Levels under Tropical Indian Conditions
}

\author{
A.S. Tayade*, S. Anusha, A. Bhaskaran and P. Govindraj \\ ICAR-Sugarcane Breeding Institute, Coimbatore, Tamil Nadu 641 007, India \\ *Corresponding author
}

\begin{tabular}{|l|}
\hline K e y w o r d s \\
$\begin{array}{l}\text { Sugarcane, } \\
\text { Recommended dose of } \\
\text { nitrogen (RDN), Early } \\
\text { and mid-late } \\
\text { varieties/genotypes }\end{array}$ \\
\hline Article Info \\
\hline $\begin{array}{l}\text { Accepted: } \\
\text { 22 April 2018 } \\
\text { Available Online: } \\
\text { 10 May 2018 }\end{array}$ \\
\hline
\end{tabular}

\section{A B S T R A C T}

Field experiment was conducted during 2015-16 and 2016-17 at ICAR-Sugarcane Breeding Institute, Coimbatore, India to study the response of six elite sugarcane varieties viz., Co 09004, Co 08009, Co 08016, Co 08020, Co 86032 and CoC 671 to higher nitrogen levels. The experiments were laid out in split plot design with three replications. The soil of the experimental site was clay loam in texture, taxonomically classified as typic haplustalf, low in organic carbon and available $\mathrm{N}$ and high in available $\mathrm{P}$ and $\mathrm{K}$, neutral in reaction with normal electrical conductivity. The prevailing climatic condition during experimentations represented tropical wet and dry climate, with the wet season lasting from October to December due to the northeast monsoon, wherein mean temperature ranged between 21.6 and $33.1{ }^{\circ} \mathrm{C}$ with a mean relative humidity of 56 to 85 per cent. As against the normal rainfall of $674.2 \mathrm{~mm}$ only 678.9 and $386.5 \mathrm{~mm}$ of rainfall were received during 2015-16 and 2016-17 crop seasons indicating the erratic behavior of rainfall. The results clearly indicated that mid-late maturing varieties Co 08009 (157.18t/ha) and Co 86032 (152.94 t/ha) equally performed well and significantly outyielded the other mid-late sugarcane varieties Co 08016 and Co 08020 . The early maturing Co 09004 (152.11 t/ha) was superior compared to the check variety check variety CoC 671 (129.12t/ha) and found to be more promising with the cane yield of improvement of 17.80 per cent. A significant progressive increase in cane yield was observed with the increase in the dose of nitrogen from 75 to $150 \%$ RDN. Application of $125 \% \mathrm{RDN}(281 \mathrm{~kg} \mathrm{~N} / \mathrm{ha})$ resulted in significantly high cane yield of 154.55 t/ha but it was at par with 100 and $150 \%$ RDN. The results of the experiment revealed that the effect of application of graded level of nitrogen on mean cane yield was significant wherein application of 100, 125 and $150 \%$ of recommended dose of nitrogen recorded significantly higher cane yield over $75 \%$ RDN. The effect of nitrogen application on juice quality was non-significant. A significant differential genotypic response to nitrogen levels was observed wherein Co 86032 the mid-late check variety exceptionally responded linearly up-to 150 of RDN whereas Co 08009, Co 08020 and Co 08016 gave better response up to $125 \% \mathrm{RDN}$ and $100 \% \mathrm{RDN}$, respectively. Both the early maturing sugarcane varieties Co 09004 and CoC 671 responded up to $125 \%$ of applied RDN. Thus the newly released early maturing variety Co 09004 with better juice qualities was found significantly superior in terms of cane height $(249.23 \mathrm{~cm}), \mathrm{NMC} / \mathrm{ha}\left(98.94 \times 10^{3}\right)$, cane yield (152.11 t/ha) and CCS yield (21.95 t/ha) over check variety CoC 671. Based on the results of the investigation it is concluded that for realizing maximum cane yield of newly released Co 09004 variety, application of $281 \mathrm{~kg}$ of nitrogen (125\% RDN) is recommended under tropical Indian condition in clay loam soil. 


\section{Introduction}

Sugarcane being a long duration exhaustive crop with heavy nutritional demand, produces a heavy 'tonnage and tends to remove substantial quantum of plant nutrients from the soil thus rendered soil less fertile and fails to produce higher crop. The production potential of sugarcane crop depends upon choice of variety and adoption improved agronomic practices in general and nitrogen nutrition in particular. Nitrogen is the primary nutrient which influences the yield and quality of cane. Earlier, Saldarringa et al., (1998) reported N fertilizer rate as one of the most influencing factor on cane yields and response to applied nitrogen is universal. Nitrogen increases the source capacity, namely leaf area index, leaf area duration, early canopy closure and rate of photosynthesis (Hunsigi, 1993). An increased sugarcane yield following nitrogen application is attributed to the increased number of tillers and yield attributes like stalk length, stem diameter and number of millable canes (Abayomi, 1987).

In pre-seasonal sugarcane Jadhav et al., (1997) reported response up to $400 \mathrm{~kg} \mathrm{~N} / \mathrm{ha}$ while for suru sugarcane $304 \mathrm{~kg} \mathrm{~N} / \mathrm{ha}$ was found optimum Sondge et al., (1992). The nitrogen requirements vary from 67.5 to $450 \mathrm{~kg} / \mathrm{ha}$ because of variation in soil type, climate, water availability, crop growth, duration of crop, cane yield patterns and cane varieties under cultivation. It is generally lower (100$225 \mathrm{~kg} / \mathrm{ha}$ ) for subtropical India in comparison to tropical states $(100-450 \mathrm{~kg} \quad \mathrm{~N} / \mathrm{ha})$. Sugarcane varieties differ widely in their nutrient requirement, wherein, Co 86032 midlate sugarcane variety with $100 \% \mathrm{RDN}$ application coupled with in-situ trash management improved cane yield by 12.91 per cent over control due to overall poor crop growth and less NMC (Tayade et al., 2016). Considerable differences in the response of sugarcane varieties to applied nitrogen has reported from Tamil Nadu (Srinivasan 1995, Ramesh and Mahadevaswamy 1996), Andhra Pradesh (Naga Madhuri et al., 2011) and in Maharashtra mid late varieties showed higher response than early varieties (Zende 1984). In sugarcane Nicole et al., (2007) reported considerable genetic variation for internal nitrogen use efficiency (iNUE i.e. biomass produced per unit tissue $\mathrm{N}$ ). Thus beneficial role of nitrogen nutrition in improving sugarcane cane yield is well established but the information on optimum nitrogen dose for the recently released high yielding, high quality and early maturing sugarcane variety Co 09004 is not available. The elite sugarcane variety Co 09004 developed at ICARSugarcane Breeding Institute, Coimbatore was notified for cultivation by Central Variety Release Committee for cultivation in Peninsular zone comprising parts of Tamil Nadu, Telengana, Andhra Pradesh Karnataka, Maharashtra, Gujarat, Madhya Pradesh, Chhattisgarh and Kerala. Therefore, the present investigation was undertaken to suggest the appropriate nitrogen dose for newly released Co 09004 sugarcane variety for realizing maximum cane yield under tropical Indian conditions.

\section{Materials and Methods}

Field experiment to study the response of six elite sugarcane varieties to higher level of nitrogen was conducted during 2015-16 and 2016-17 at ICAR-Sugarcane Breeding Institute, Coimbatore $\left(11^{0} \mathrm{~N}, 77^{\circ} \mathrm{E}\right.$ at an altitude of $427 \mathrm{~m}$ above mean sea level), India. The experiment with three replications was laid out in split plot design with six elite varieties viz. Co 08009, Co 08016, Co 08020 , Co 09004, CoC 671 and Co 86032 in main plot and four nitrogen levels i.e. 75,100,125 and $150 \%$ of RDN $(100 \%$ RDN $=225 \mathrm{~kg} / \mathrm{ha})$ were accommodated in sub-plots. The soil of the experimental site was clay loam in texture, moderately drained with adequate provision 
for good drainage, taxonomically classified as typic haplustalf, low in organic carbon $(0.48 \%)$, and $\mathrm{N}(228.0 \mathrm{~kg} / \mathrm{ha})$, high in $\mathrm{P}(50.3$ $\mathrm{kg} / \mathrm{ha})$ and $\mathrm{K}(875.0 \mathrm{~kg} / \mathrm{ha})$, neutral in reaction (7.52) and exhibiting EC of $0.86 \mathrm{~d} \mathrm{~S} \mathrm{~m}^{-1}$. Two budded sugarcane setts planted at $90 \mathrm{~cm}$ row spacing with a seed rate of 40 setts per six meter furrow length. The plot size was $9 \mathrm{~m} \times 6$ $\mathrm{m}$ ( 6 rows of 6 meter length spaced $0.9 \mathrm{~m}$ ) for both plant and ratoon crops. Recommended dose of fertilizer for the zone i.e. 225:62.5:120 $\mathrm{kg} \mathrm{N} \mathrm{P}_{2} \mathrm{O}_{5} \mathrm{~K}_{2} \mathrm{O} /$ ha was applied to the plant and ratoon crops, respectively, as per the following scheduled. In plant crop, before placing setts in the furrows, full dose of $\mathrm{P}$ was applied in furrows beneath the cane setts whereas $\mathrm{N}$ and $\mathrm{K}$ were applied in two splits at partial (45 days after planting) and full earthing up (90 days after planting) while in ratoon crop $25 \%$ extra nitrogen (56.25 k N/ha) and full dose of $\mathrm{P}$ were applied at time of ratoon initiation and the remaining 225:120 $\mathrm{N}$ and $\mathrm{K}$ were applied in two splits at partial (30 days after ratoon initiation) and full earthing up (60 days after ratoon initiation). The trial was initiated in January 2015 and harvested 12 months later in December 2015 subsequently ratoon sugarcane crop was taken during January 2016. The climate of the experimental site is characterized as tropical wet and dry climate, with the wet season lasting from October to December due to the northeast monsoon.

A total rainfall of 678.9 and $386.5 \mathrm{~mm}$ spread over 46 and 33 rainy days was received during 2015-16 and 2016-17 as against the average rainfall of $674.2 \mathrm{~mm}$. Observation on germination count in plant crop at 30 days and 45 days after planting were recorded. In plant and first ratoon crop, at harvest, five plants were randomly selected from each plot for estimation of yield attributes (cane height, single cane weight, and cane girth) and actual cane yield/plot was recorded at harvest. Sugarcane juice was analyzed for Brix, Pol $(\%)$ and purity (\%) as per standard methods of
Meade and Chen (1977). Commercial cane sugar \% was worked out using the formula [(Sucrose \% x 1.022) - (Brix x 0.292)]. CCS yield ( $\mathrm{t} / \mathrm{ha}$ ) was calculated by following the formula [(CCS\% $x$ cane yield $\mathrm{t} / \mathrm{ha}) / 100]$. Analysis of variance was performed for cane yielding attributes, cane yield and juice quality parameters following a split plot design combined across years (Gomez and Gomez 1984) using MSTAT-C (model no. 15). Differences between mean values were separated out using least significant differences (LSD) at $\mathrm{P}<0.05$.

\section{Results and Discussion}

\section{Growth and yield attributes}

The germination count recorded in plant crop at 30 and 45 days after planting differed significantly with sugarcane varieties whereas no significant effect of graded level of nitrogen application was noticed on germination. Among the mid late varieties, the varieties Co 08016 recorded significantly higher germination count of 60.35 and 87.42 per cent over the check variety Co 86032 at 30 and 45 days after planting, respectively. Cane length $(\mathrm{cm})$ recorded at harvest differed significantly within the elite sugarcane varieties (Table 1). Variety Co 08009 recorded the significantly higher cane length (253.55 $\mathrm{cm})$ than Co 08016 and Co 08020 whereas it was on par with check variety Co 86032 . Early variety Co 09004 recorded significantly taller cane than $\mathrm{CoC} 671$ sugarcane variety. Significant differences for single cane weight $(\mathrm{kg})$ were observed in varieties. Amongst the different mid late varieties, Co 86032 sugarcane variety registered significantly higher single cane weight $(1.39 \mathrm{~kg})$ than Co 08016 and with regard to early varieties, CoC 671 with mean cane weight of $1.52 \mathrm{~kg}$ was found significantly superior over Co 09004 $(1.28 \mathrm{~kg})$. Genotypic variations for cane girth during plant and ratoon crops were significant 
wherein mid late varieties Co 86032 and Co 08020 recorded significantly thicker cane than the Co 08009 and Co 08016. In case of early sugarcane varieties $\mathrm{CoC} 671$ the cane thickness $(29.30 \mathrm{~mm})$ was significantly higher than Co 09004 (25.26 mm). The differences in single cane weight, cane length and thickness could be attributed to the inherent differential phenotypic makeup of the evaluated sugarcane varieties. Significant variations for yield attributing characters like cane length and cane diameter among the sugarcane varieties were also reported earlier by Bharathalakshmi et al., (2003) and Naga Madhuri et al., (2011). Application of higher levels of nitrogen did not influence the single cane weight, cane length and diameter to any appreciable extent. This in conformity with the finding of Esther et al., (2012) and Shukla (2007) who have reported no variation in single cane weight and cane girth due to application of higher levels of nitrogen.

\section{Number of millable canes}

Number of millable canes (000/ha) was influenced significantly by the varieties whereas graded level of nitrogen application could not improve it significantly. The mid late varieties Co 08009 and Co 08016 with $130.63 \times 10^{3}$ and $131.55 \times 10^{3} \mathrm{NMC} /$ ha were found significantly superior over Co 86032 and Co 08020 sugarcane varieties. The highest NMC recorded by Co 08009 variety over the rest of mid late varieties in ratoon crop is suggesting its good ratooning ability, similarly Co 09004 with significantly higher NMC (98.94 x $\left.10^{3} \mathrm{NMC} / \mathrm{ha}\right)$ was found to be more promising than $\mathrm{CoC} 671\left(87.47 \times 10^{3}\right.$ $\mathrm{NMC} / \mathrm{ha}$ ). Our findings were in conformity with the result of Garside and Bell (2009) who reported the substantial cultivar differences for number of millable cane. Number of millable cane sowed no variation due to nitrogen application. Similar results were also reported by Naga Madhuri et al., (2011).

\section{Cane yield}

Cane yield was influenced significantly by sugarcane varieties wherein mid-late varieties Co 08009 (157.18t/ha) and Co 86032 (152.94 t/ha) recorded more or less same cane yield and significantly out-yielded the other midlate sugarcane varieties Co 08016 and Co 08020 (Table 2). With 17.80 per cent cane yield advantage, early maturing Co 09004 $(152.11 \mathrm{t} / \mathrm{ha})$ was found significantly more promising over the counterpart check variety CoC 671 (129.12t/ha).

Higher cane yield recorded by Co 09004 over CoC 671 was primarily attributed to the early crop vigor and good agronomic field stand at 45 DAP (62.56\% germination), significantly taller cane and more NMC (98.94 x 10\%3a). Similarly Co 09004 the early maturing variety showed an average of $17.84 \%$ improvement in cane yield over the best standard CoC 671 across 17 centres under All India Co-ordinated Research Project (Sugarcane) of peninsular zone (ICAR-SBI, 2017).

A significant progressive increase in cane yield was observed with the increase in the dose of nitrogen from 75 to $150 \%$ RDN. Application of $125 \%$ RDN (281kg N/ha) had resulted in statistically significant highest cane yield of 154.55 t/ha over $75 \%$ RDN but it was at par with 100 and $150 \%$ RDN. Similar response to higher levels of nitrogen was also reported by Naga Madhuri et al., 2011. Although the interaction effects in pooled data for varieties and nitrogen levels were absent, however, with the highest cane yield of 172.38 t/ha, mid-late sugarcane variety Co 86032 responded linearly up-to $150 \%$ of RDN and the yield response was exceedingly higher by $9.95,16.39$ and $32.62 \%$ over 75,100 and 125 $\%$ of RDN level, respectively. Application of $100 \%$ RDN was found optimum for realizing higher cane yield (130.84 t/ha) of Co 08016. 
Table.1 Effect of nitrogen application on germination and yield attributing parameters of elite sugarcane varieties

\begin{tabular}{|c|c|c|c|c|c|c|c|c|c|c|c|}
\hline \multirow[b]{3}{*}{ Varietiess } & \multicolumn{2}{|c|}{$\begin{array}{c}\text { Germination Count } \\
(\%)\end{array}$} & \multirow{2}{*}{\multicolumn{3}{|c|}{$\begin{array}{l}\text { Cane length } \\
\text { (cm) }\end{array}$}} & \multirow{2}{*}{\multicolumn{3}{|c|}{ Single Cane Weight (Kg) }} & \multirow{2}{*}{\multicolumn{3}{|c|}{$\begin{array}{l}\text { Cane Girth } \\
\qquad(\mathrm{mm})\end{array}$}} \\
\hline & \multirow{2}{*}{$\begin{array}{c}30 \text { DAP } \\
\text { Plant } \\
\text { crop }\end{array}$} & \multirow{2}{*}{$\begin{array}{l}45 \text { DAP } \\
\text { Plant } \\
\text { crop }\end{array}$} & & & & & & & & & \\
\hline & & & $\begin{array}{l}\text { Plant } \\
\text { crop }\end{array}$ & Ratoon & Pooled & $\begin{array}{l}\text { Plant } \\
\text { crop }\end{array}$ & Ratoon & Pooled & $\begin{array}{l}\text { Plant } \\
\text { crop }\end{array}$ & Ratoon & Pooled \\
\hline Co 08009 & 39.55 & 47.84 & 265.16 & 241.95 & 253.55 & 1.33 & 1.10 & 1.22 & 25.28 & 23.98 & 24.63 \\
\hline Co 08016 & 60.35 & 87.42 & 227.50 & 203.25 & 215.38 & 1.17 & 0.89 & 1.03 & 25.26 & 23.92 & 24.59 \\
\hline Co 08020 & 59.37 & 64.60 & 249.16 & 200.69 & 224.92 & 1.56 & 1.04 & 1.30 & 29.28 & 26.07 & 27.68 \\
\hline Co 09004 & 49.05 & 62.56 & 267.91 & 230.55 & 249.23 & 1.43 & 1.14 & 1.28 & 25.39 & 25.12 & 25.26 \\
\hline СoC 671 & 46.37 & 53.51 & 245.66 & 215.44 & 230.55 & 1.70 & 1.34 & 1.52 & 30.02 & 28.59 & 29.31 \\
\hline Co 86032 & 49.05 & 62.56 & 256.25 & 211.51 & 233.88 & 1.63 & 1.14 & 1.39 & 28.96 & 27.07 & 28.02 \\
\hline SEd & 2.44 & 3.11 & 12.17 & 11.24 & 8.28 & 0.14 & 0.07 & 0.08 & 1.42 & 0.74 & 0.80 \\
\hline CD at $5 \%$ & 4.91 & 6.27 & NS & 25.05 & 17.27 & 0.31 & 0.16 & 0.16 & 3.164 & 1.65 & 1.67 \\
\hline \multicolumn{12}{|l|}{$\begin{array}{l}\text { Nitrogen } \\
\text { levels }\end{array}$} \\
\hline $\mathrm{N}_{75}$ & 52.00 & 63.77 & 258.11 & 217.03 & 237.57 & 1.51 & 1.12 & 1.31 & 26.98 & 25.86 & 26.42 \\
\hline $\mathrm{N}_{100}$ & 50.66 & 61.77 & 254.39 & 214.92 & 234.65 & 1.50 & 1.10 & 1.29 & 27.47 & 25.65 & 26.56 \\
\hline $\mathrm{N}_{125}$ & 50.09 & 63.97 & 248.77 & 223.61 & 236.94 & 1.49 & 1.18 & 1.33 & 27.82 & 26.17 & 27.00 \\
\hline $\mathbf{N}_{150}$ & 48.25 & 61.47 & 245.06 & 213.36 & 229.18 & 1.40 & 1.06 & 1.23 & 27.19 & 25.49 & 26.34 \\
\hline SEd & 1.99 & 2.54 & 6.92 & 7.28 & 5.02 & 0.07 & 0.07 & 0.05 & 0.66 & 0.77 & 0.50 \\
\hline CD at $5 \%$ & NS & NS & NS & NS & NS & NS & NS & NS & NS & NS & NS \\
\hline \multicolumn{12}{|l|}{$\mathbf{V} * \mathbf{N}$} \\
\hline SEd & 4.88 & 6.23 & 16.95 & 17.85 & 12.31 & 0.19 & 0.18 & 0.13 & 1.62 & 1.88 & 1.24 \\
\hline CD at $5 \%$ & NS & NS & NS & NS & NS & NS & NS & NS & NS & NS & NS \\
\hline
\end{tabular}


Table.2 Effect of nitrogen application on NMC (000/ha) cane yield (t/ha) and CCS yield (t/ha) of elite sugarcane varieties

\begin{tabular}{|c|c|c|c|c|c|c|c|c|c|}
\hline \multirow[t]{2}{*}{ Varietiess } & \multicolumn{3}{|c|}{ NMC(000/ha) } & \multicolumn{3}{|c|}{ Cane Yield(t/ha) } & \multicolumn{3}{|c|}{ CCS Yield (t/ha) } \\
\hline & $\begin{array}{l}\text { Plant } \\
\text { crop }\end{array}$ & Ratoon I & Pooled & Plant crop & Ratoon I & Pooled & $\begin{array}{l}\text { Plant } \\
\text { crop }\end{array}$ & Ratoon I & Pooled \\
\hline Co 08009 & 125.74 & 135.51 & 130.63 & 177.07 & 137.28 & 157.18 & 23.57 & 19.06 & 21.32 \\
\hline Co 08016 & 134.23 & 128.87 & 131.55 & 143.51 & 98.55 & 121.03 & 20.25 & 13.32 & 16.79 \\
\hline Co 08020 & 102.90 & 114.00 & 108.45 & 171.68 & 123.18 & 147.43 & 22.58 & 16.66 & 19.62 \\
\hline Co 09004 & 94.03 & 103.85 & 98.943 & 171.89 & 132.32 & 152.11 & 25.19 & 18.62 & 21.91 \\
\hline CoC 671 & 89.37 & 85.56 & 87.471 & 145.58 & 112.66 & 129.12 & 20.67 & 17.20 & 18.93 \\
\hline Co 86032 & 111.18 & 116.74 & 113.96 & 174.90 & 130.98 & 152.94 & 23.06 & 18.10 & 20.58 \\
\hline SEd & 4.91 & 5.48 & 3.68 & 5.75 & 5.71 & 4.05 & 1.06 & 0.80 & 0.66 \\
\hline CD at $5 \%$ & 10.95 & 12.21 & 7.68 & 12.83 & 12.73 & 8.46 & 2.36 & 1.78 & 1.38 \\
\hline \multicolumn{10}{|l|}{$\begin{array}{c}\text { Nitrogen } \\
\text { levels }\end{array}$} \\
\hline $\mathrm{N}_{75}$ & 109.41 & 112.18 & 110.79 & 152.39 & 105.22 & 128.80 & 20.92 & 15.07 & 18.00 \\
\hline $\mathbf{N}_{100}$ & 109.82 & 115.18 & 112.50 & 169.89 & 120.76 & 145.32 & 22.70 & 16.41 & 19.55 \\
\hline $\mathrm{N}_{125}$ & 109.17 & 115.15 & 112.16 & 171.65 & 137.44 & 154.55 & 24.08 & 19.70 & 21.89 \\
\hline $\mathbf{N}_{150}$ & 109.90 & 113.85 & 111.88 & 162.49 & 126.57 & 144.53 & 22.51 & 17.47 & 19.99 \\
\hline SEd & 3.02 & 4.19 & 2.58 & 7.78 & 6.65 & 5.11 & 1.09 & 0.90 & 0.71 \\
\hline CD at $5 \%$ & NS & 8.51 & NS & NS & 13.49 & 10.20 & NS & 1.83 & 1.41 \\
\hline \multicolumn{10}{|l|}{$\mathbf{V x N}$} \\
\hline SEd & 7.41 & 10.28 & 6.33 & 19.06 & 16.29 & 12.53 & 2.68 & 2.21 & 1.74 \\
\hline CD at $5 \%$ & 15.04 & 20.85 & NS & NS & NS & NS & NS & NS & NS \\
\hline
\end{tabular}


Table.3 Effect of nitrogen application on juice quality parameters of elite sugarcane varieties

\begin{tabular}{|c|c|c|c|c|c|c|c|c|c|c|c|c|}
\hline \multirow{2}{*}{$\begin{array}{c}\text { Treatments } \\
\text { Varietiess }\end{array}$} & \multicolumn{3}{|c|}{ Brix (\%) } & \multicolumn{3}{|c|}{ Sucrose (\%) } & \multicolumn{3}{|c|}{ Purity (\%) } & \multicolumn{3}{|c|}{ CCS (\%) } \\
\hline & $\begin{array}{l}\text { Plant } \\
\text { crop }\end{array}$ & Ratoon & $\begin{array}{l}\text { Poole } \\
\text { d }\end{array}$ & $\begin{array}{l}\text { Plant } \\
\text { crop }\end{array}$ & Ratoon & pooled & $\begin{array}{l}\text { Plant } \\
\text { crop }\end{array}$ & Ratoon & $\begin{array}{c}\text { poole } \\
\text { d }\end{array}$ & $\begin{array}{l}\text { Plant } \\
\text { crop }\end{array}$ & Ratoon & Pooled \\
\hline Co 08009 & 20.65 & 20.97 & 20.81 & 19.85 & 19.10 & 19.47 & 92.34 & 92.49 & 92.41 & 13.49 & 13.87 & 13.68 \\
\hline Co 08016 & 21.34 & 21.12 & 21.23 & 20.74 & 20.09 & 20.42 & 94.08 & 90.84 & 92.46 & 14.30 & 13.52 & 13.91 \\
\hline Co 08020 & 20.29 & 21.06 & 20.67 & 19.54 & 18.87 & 19.20 & 92.93 & 91.46 & 92.20 & 13.36 & 13.52 & 13.44 \\
\hline Co 09004 & 21.50 & 21.82 & 21.66 & 21.14 & 20.67 & 20.91 & 96.05 & 90.71 & 93.38 & 14.85 & 13.94 & 14.39 \\
\hline CoC 671 & 21.34 & 21.60 & 21.47 & 20.81 & 20.24 & 20.53 & 94.81 & 95.59 & 95.20 & 14.46 & 14.68 & 14.57 \\
\hline Co 86032 & 20.017 & 20.69 & 20.35 & 19.38 & 18.81 & 19.09 & 93.95 & 93.97 & 93.96 & 13.37 & 13.89 & 13.63 \\
\hline SEd & 0.37 & 0.28 & 0.23 & 0.35 & 0.43 & 0.28 & 0.50 & 1.30 & 0.70 & 0.33 & 0.28 & 0.21 \\
\hline CD at $5 \%$ & 0.83 & 0.64 & 0.49 & 0.80 & 0.96 & 0.58 & 1.13 & 2.90 & 1.46 & 0.74 & 0.63 & 0.45 \\
\hline \multicolumn{13}{|l|}{ Nitrogen levels } \\
\hline $\mathrm{N}_{75}$ & 20.99 & 21.21 & 21.10 & 20.24 & 19.67 & 19.96 & 93.67 & 91.58 & 93.54 & 13.98 & 13.88 & 13.93 \\
\hline $\mathbf{N}_{100}$ & 20.46 & 21.02 & 20.74 & 19.81 & 19.13 & 19.47 & 93.35 & 91.58 & 92.36 & 13.57 & 13.49 & 13.53 \\
\hline $\mathrm{N}_{125}$ & 21.06 & 21.71 & 21.39 & 20.61 & 19.99 & 20.30 & 94.80 & 91.58 & 94.25 & 14.28 & 14.48 & 14.38 \\
\hline $\mathrm{N}_{150}$ & 20.91 & 20.90 & 20.91 & 20.32 & 19.73 & 20.02 & 94.27 & 91.58 & 92.93 & 14.06 & 13.77 & 13.92 \\
\hline SEd & 0.33 & 0.18 & 0.19 & 0.35 & 0.41 & 0.27 & 0.66 & 0.97 & 0.58 & 0.32 & 0.27 & 0.21 \\
\hline CD at $5 \%$ & NS & 0.37 & 0.38 & NS & NS & 0.55 & NS & 1.97 & 1.17 & NS & 0.55 & 0.42 \\
\hline \multicolumn{13}{|l|}{$\mathbf{V x N}$} \\
\hline SEd & 0.82 & 0.44 & 0.47 & 0.90 & 1.01 & 0.67 & 0.66 & 2.38 & 1.44 & 0.80 & 0.67 & 0.52 \\
\hline CD at $5 \%$ & NS & NS & 0.93 & 1.83 & NS & 1.35 & NS & NS & NS & NS & NS & NS \\
\hline
\end{tabular}


Fig.1 Soil nutrients status after sugarcane harvest

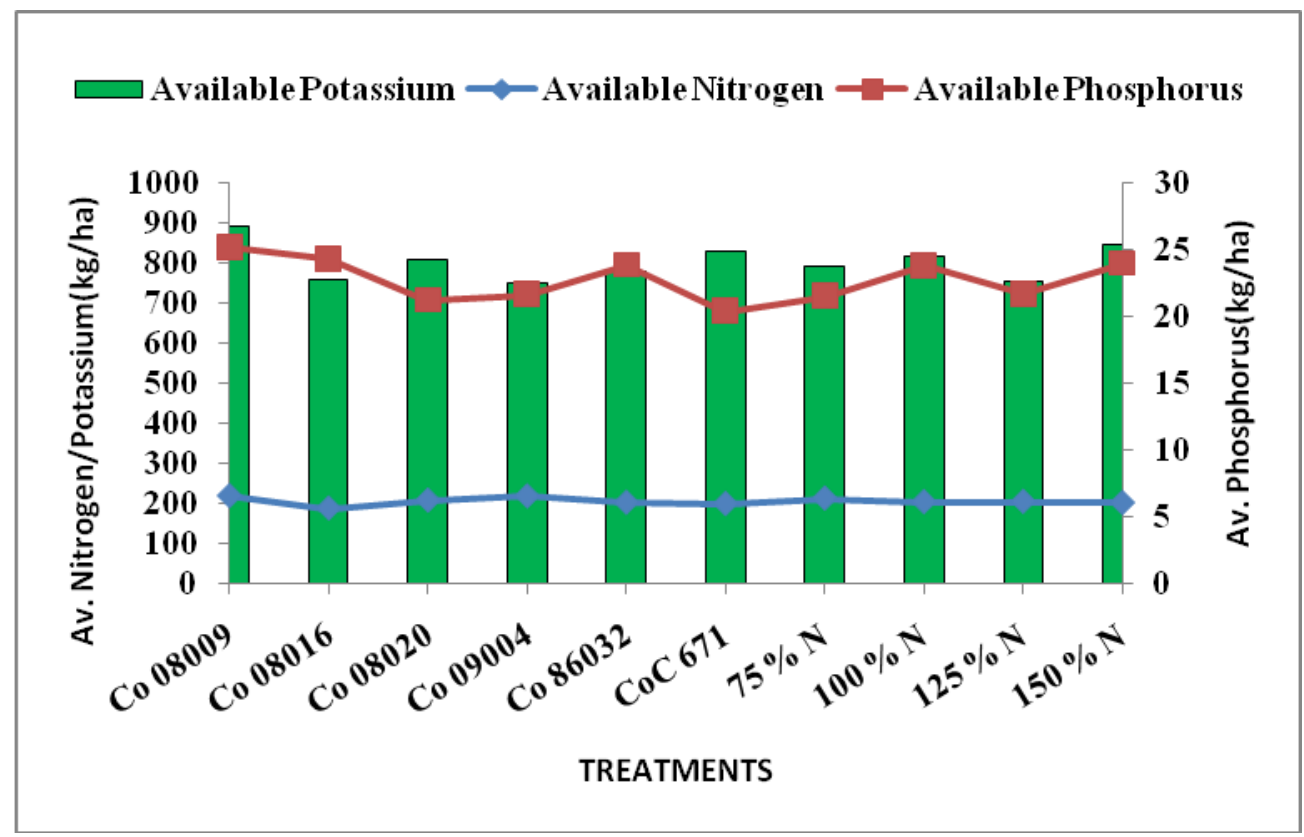

The response of other two mid-late varieties Co 08009 and Co 08020 at $125 \%$ RDN was the highest and recorded mean cane yield of 171.06 and 167.64 t/ha, respectively. Cane yield in early sugarcane varieties were comparatively less than the mid-late sugarcane varieties and both the early varieties Co 09004 and $\mathrm{CoC} 671$ responded up to $125 \%$ of applied RDN and did not yield more with nitrogen application above $125 \%$ of RDN. Earlier studies Rakkiyappan, (1981) and Thakur et al., (1991) also had reported the differential response of sugarcane varieties to varied level nitrogen application.

\section{CCS yield}

The data on CCS yield (t/ha) presented in Table 2 indicated that CCS yield was influenced significantly due to different sugarcane varieties. Amongst the different sugarcane varieties Co 09004 recorded the highest CCS yield of 21.91 t/ha and was found significantly superior over Co 08016, Co 08020 and $\mathrm{CoC}$ 671. Higher tonnage (152.11 t/ha) coupled with more sucrose content (20.91\%) in cane juice of Co 09004 would have culminated in higher sugar yield. Application of graded levels of nitrogen could not influence the CCS yield significantly, however highest CCS yield was obtained with $125 \%$ RDN (281 kg N/ha). Esther et al., (2012) and Sathyavelu et al., (1999) also reported negative response of higher level of nitrogen application on CCS yield. The interaction effects of varieties and nitrogen application on CCS yield were more distinct in treatment combinations of Co $09004 \times 100$ $\%$ of RDN which recorded the highest CCS yield (24.61 t/ha) than rest of treatment combinations.

\section{Juice quality characteristics}

The juice extracted from cane assumes greater importance as it is directly related to the commercial output of sugarcane. The brix values, sucrose content and purity percentage determine the quality of cane. In the present investigation brix (\%), sucrose content (\%), purity (\%) and CCS \% estimated at harvest differed significantly due to different 
sugarcane varieties (Table 3). The sugarcane varieties Co 08016, Co 09004 and CoC 671 recorded more or less similar mean brix (\%) and sucrose $(\%)$ and were found significantly superior over Co 86032 the standard sugarcane variety. The interaction effects of varieties and nitrogen $(\mathrm{V} \times \mathrm{N})$ were found significant for brix and sucrose percentage during pooled result wherein early variety $\mathrm{Co}$ 09004 at $125 \% \mathrm{RDN}(281 \mathrm{~kg} \mathrm{~N} / \mathrm{ha})$ and 150 $\% \quad \mathrm{RDN}(337.5 \mathrm{~kg} \mathrm{~N} / \mathrm{ha})$ recorded the maximum brix \% (22.09) and sucrose \% (22.07) than the rest of treatment combinations. Higher sucrose values for Co 08016, Co 09004 and $\mathrm{CoC} 671$ indicated better genetic potentials of these varieties to accumulate more sucrose in juice. With regard to mean purity percentage it was significantly higher for $\mathrm{CoC} 671$ variety over the rest of sugarcane varieties. The Co 09004 and $\mathrm{CoC} 671$ sugarcane varieties had a significant higher edge over other sugarcane varieties with respect to CCS (\%) the possible reason for this might be, higher sucrose \% recorded by these two varieties, which is responsible for improvement in commercial cane sugar. The juice qualities are mainly determined by the genetic makeup of the varieties. This is in accordance with the finding of Naga Madhuri et al., (2011) who reported that varieties exhibited their genetic potential with respect to juice sucrose. Similarly Garside and Bell (2009) reported the significant cultivar differences for cane yield and CCS yield. Application of varied levels of nitrogen influenced the juice quality parameters significantly wherein application of $125 \%$ RDN (281 kg N/ha) showed higher edge over sub-optimal (75\%RDN) and superoptimal (150\% RDN) doses of nitrogen. A significant deterioration in brix (\%), purity (\%) and CCS (\%) was observed due application of $150 \%$ RDN over $125 \%$ RDN. The negative effect of the additional nitrogen dose may be due to the excess amount of nitrogen which delayed maturity and subsequently resulted in the reduced purity $\%$. This was in conformity with the finding of Singandhupe et al., (2008). Similarly Hemalatha (2015) also observed declined in brix, sucrose and purity of sugarcane juice at application of higher level of nitrogen $(299 \mathrm{~kg}$ N/ha). Studies by Fritz (1974) and Wiedenfeld (1997) had shown deterioration of cane juice quality because of abundance of nitrogen in plant during ripening phase, which was detrimental to sucrose accumulation and ultimately to the sugar yield.

\section{Soil nutrient status after sugarcane harvest}

The soil available $\mathrm{N}, \mathrm{P}, \mathrm{K}$ contents after harvest of ratoon crop did not differ significantly due to different sugarcane varieties and nitrogen levels (Fig.1), however, compared to other sugarcane varieties higher magnitude soil available N, P and K (217.18, 25.21 and $889.59 \mathrm{~kg}$ ha-1) was observed in Co 08009 treatment.

The results clearly indicated that mid-late varieties Co 08009 (157.18t/ha) and Co 86032 (152.94 t/ha) equally performed well and significantly out-yielded the other mid-late sugarcane varieties Co 08016 and Co 08020. With 17.80 per cent cane yield advantage, early maturing Co 09004 (152.11 t/ha) was found significantly more promising over the counterpart check variety CoC 671 (129.12t/ha). A significant progressive increase in cane yield was observed with the increase in the dose of nitrogen from 75 to $150 \%$ RDN. Application of $125 \%$ RDN $(281 \mathrm{~kg} \mathrm{~N} / \mathrm{ha})$ resulted in significantly highest cane yield of $154.55 \mathrm{t} / \mathrm{ha}$ but it was at par with 100 and $150 \%$ RDN. In a differential genotypic response to higher nitrogen levels, Co 86032 mid-late sugarcane variety responded linearly up-to 150 of RDN whereas $100 \%$ RDN was found optimum for realizing higher cane yield of Co 08016 under peninsular zone. The other two mid-late 
varieties i.e. Co 08009 and Co 08020 gave the highest cane yield at application of $125 \%$ RDN. The newly released promising sugarcane variety Co 09004 was found significantly superior over the local check CoC 671 sugarcane variety and linearly responded unto $125 \%$ of RDN application; hence for realizing maximum cane yield in clay loam soil of tropical Indian condition application of $281 \mathrm{~kg}$ of nitrogen (125\% $\mathrm{RDN}$ ) is recommended.

\section{References}

Abayomi, A.Y.1987. Growth, yield and crop quality performance of sugarcane cultivar Co 957 under different rates of nitrogen and potassium application fertilizers. Journal of Agricultural Sciences (Cambridge) 109:285-295.

Bharathalakshmi, M., T. Chitkala Devi, I.V. Narasima Rao and K.L. Rao. 2003. Effect of time of nitrogen application on yield and quality of early maturing sugarcane varieties under rainfed conditions. Sugar Tech 5(1\&2):73-76.

Esther Shekinah, B. Sundara and P. Rakkiyappan. 2012. Relative significance of $\mathrm{N}$ nutrition on yield, quality and ethanol in sugarcane (Saccharum species hybrid) plant and ratoon system. Sugar Tech 14 (2): 134137.

Fritz, J. 1974. Effect of fertilizer application upon sucrose percent in cane. Proc. Int. Soc. Sugarcane Technologist152:162632

Garside, A.L., and M.J. Bell. 2009. Row spacing and planting density effects on the growth and yield of sugarcane. Crop and Pasture 60:555-565.

Gomez, K. A., and A. A. Gomez, 1984. Statistical Procedures for Agricultural Research, Wiley, Singapore.
Hemlatha S.2015. Impac of nitrogen fertilization on quality of sugarcane under fertigation. IJRSI 2(3):37-39.

Hunsigi, G. 1993. Production of sugarcanetheory and practice. Berlin: SpringerVerlag.

ICAR-SBI.2017. Research achievements Annual Report. Pp.20

Jadhav, G.S., S.R. Oza, V.D. Sondge, and D.A. Chavan. 1997. Response of preseason sugarcane to irrigation and nitrogen levels. Journal of Maharashtra Agricultural Universities 22(3): 313315.

Meade, G.P., and J.C.P. Chen. 1977. Cane Sugar Handbook, 515 - 545 10th ed. New York: John Wiley and Sons.

Naga Madhuri, K.V., M. Hemanth Kumar, and N.V. Sarala. 2011. Influence of higher doses of nitrogen on yield and quality of early maturing sugarcane varieties. Sugar Tech 13 (1): 96-98.

Nicole, R., A. Fletcher, A. Whan, C. Critchley, N. Von Wire'n, P. Lakshmanan, and S. Schmidt. 2007. Sugarcane varieties differ in internal nitrogen use efficiency. Functional Plant Biology 34 (12): 1122-1129.

Rakkiyappan, P. 1991. Time of application of nitrogen. Annual Report, Sugarcane Breeding Institute, 1990-91, p: 48.

Ramesh, P., and M. Mahadevaswamy. 1996. Agronomic practices for some promising sugarcane varieties in tropical India. Indian Sugar 46: 719722.

Saldarrianga, A.S., Angulo, A. E., Soto, R. E. and A. Leyva, 1998. Proc. InterAmerican Sugarcane Seminar, Crop Production and Mechanization, Miami, Florida. 9 - 11, September 1998. pp. $208-225$.

Sathyavelu, A., R. Paneerselvam, S. Nasir Ahmed and S. Giridharan. 1999. Studies on the different level of ' $N$ ' and time of 
harvest on the yield and quality of sugarcane. Bharatiya Sugar 25:17-21.

Shukla, S.K. 2007. Productivity and economics of high-sugar genotypes of sugarcane (Saccharum officinarum hybrid complex) in plant-ratoon system under various planting season and fertility levels. Indian Journal of Agronomy 52: 164-167.

Singandhupe, R.B., M. C. Bankar, P.S.B. Anand, and N.G. Patil. 2008. Management of drip irrigated sugarcane in western India. Archives of Agronomy and Soil Science. 54(6): 629-649.

Sondge, V.D., R.P. Rodge, and V.V. Dapiphale. 1992. Optimization of irrigation and nitrogen levels for suru planted sugarcane. Journal of Maharashtra Agricultural Universities 17 (2): 244-247.

Srinivasan, T.R. 1995. Crop production technologies I. In Sugarcane production manual, ed. K.C. Alexander and S.
Arulraj, 26-42.Coimbatore: Sugarcane Breeding Institute.

Tayade, A.S., P. Geetha, R. Dhanapal, and K. Hari. 2016. Effect of in-situ trash management on sugarcane under wide row planting system. Journal of Sugarcane Research 6 (1): 35-41.

Thakur, R., Jain, R.C. Sharma, S.R., Thakur, G.L. and Nema, D.P. 1991. Response of promising early, mid-late and late varieties of sugarcane of the region to nitrogen application. Bharatiya Sugar, 61(10): 1125.

Wiedenfeld, R.P. 1997. Sugarcane responses to $\mathrm{N}$ fertilizer application on clay soils. Journal of the American Society Sugarcane Technologist 17: 14-27.

Zende, G.K. 1984. Seminar on 'Efficient use of fertilizers for increasing sugarcane productivity - a comprehensive paper, SA1-SA139. Pune: Deccan Sugar Technologists Association.

\section{How to cite this article:}

Tayade, A.S., S. Anusha, A. Bhaskaran and Govindraj, P. 2018. Response of Elite Sugarcane Varieties/Genotypes to Higher Nitrogen Levels under Tropical Indian Conditions. Int.J.Curr.Microbiol.App.Sci. 7(05): 3377-3387. doi: https://doi.org/10.20546/ijcmas.2018.705.395 